\title{
External and 'Internal Factors Influence Fruit Tolerance to Low-oxygen Atmospheres
}

\author{
Dangyang Ke and Adel A. Kader ${ }^{1}$ \\ Department of Pomology University of California, Davis, CA 95616
}

\begin{abstract}
Additional index words. apple, Asian pear, cherry, nectarine, plum, temperature, respiration rate, gas diffusion, soluble solids concentration, ethanol, off-flavor, taste, Malus domestica, Prunus persica, Prunus salicina, Pyrus serotina, Prunus avium
\end{abstract}

\begin{abstract}
Fruits of 'Bing' cherry (Prunus avium L.), 'Red Jim' nectarine (Prunuspersica L.), 'Angeleno' plum (Prunus salicina, L.), 'Yellow Newtown' and 'Granny Smith' apples (Malus domestica Borkh.), and '20th Century' pear (Pyrus serotina L.) were treated with $0.25 \%$ or $0.02 \% \mathrm{O}_{2}$ (balance $\mathrm{N}_{2}$ ) at 0,5 , or $10 \mathrm{C}$ to study the effects of these insecticidal low- $\mathrm{O}_{2}$ atmospheres on their postharvest physiology and quality attributes. Development of alcoholic off-flavor was associated with ethanol accumulation, which was the most common and important detrimental effect that limited fruit tolerance to low $\mathrm{O}_{2}$. Relatively higher storage temperature (T), higher respiration rate (R), and greater resistance to gas diffusion $(r)$ enhanced while relatively higher $\mathrm{O}_{2}$ concentration $(\mathrm{C})$ and higher soluble solids concentration (SSC) reduced off-flavor development. Using a SAS computer program to do multiple regression analysis with T, C, $\mathrm{R}, \mathrm{r}$, and SSC as variables, models were developed for prediction of fruit tolerance to insecticidal low-O, atmospheres. Comparison of fruit tolerances and published information on the times required to completely kill specific insects by $\mathrm{O}_{2}$ levels at or below $1 \%$ suggests that low- $\mathrm{O}_{2}$ atmospheres have a good potential for use as postharvest quarantine treatments for some fruits.
\end{abstract}

The potential of short-term exposure to $\mathrm{O}_{2}$ levels < $1 \%$ and/ or $\mathrm{CO}_{2}$ levels $>50 \%$ to replace chemical fumigation for postharvest insect control to meet quarantine requirements of fresh fruits and vegetables has recently been extensively investigated (Ali Niazee et al., 1989; Benshoter, 1987; Dentener et al., 1990; Kosittrakun, 1989; Soderstrom et al., 1987, 1990). Controlled atmosphere (CA) treatments can be used for quarantine procedures only when the fresh commodities can tolerate low$\mathrm{O}_{2}$ and/or high- $\mathrm{CO}_{2}$ conditions longer than the time required to completely kill the insects of concern. We have investigated tolerances of diverse fruits to insecticidal CA conditions (Ke and Kader, 1989, 1990; Ke et al., 1990, 1991a, b, and c). Chen et al. (1981) reported that sweet cherries stored in $0.5 \%$ to $1 \%$ $\mathrm{O}_{2}$ at $-1.1 \mathrm{C}$ for 35 days maintained stem greenness, desirable fruit color, and a higher level of titratable acidity than those kept in air. Patterson (1982) showed that keeping sweet cherries in $1 \% \mathrm{O}_{2}$ at 0 to $1.7 \mathrm{C}$ for 5 to 8 weeks maintained SSC and red pigmentation, but did not have a significant effect on firmness. Treatments with low $\mathrm{O}_{2}$ and/or high $\mathrm{CO}_{2}$ retarded softening and color changes and reduced respiration and ethylene production rates of peaches and nectarines (Smilanick and Fouse, 1989; Wang and Anderson, 1982). However, if fresh fruits were exposed to stress $\mathrm{O}_{2}$ and/or $\mathrm{CO}_{2}$ levels for a period longer than the time they could tolerate, detrimental effects such as abnormal ripening, flesh browning, and accumulation of ethanol and acetaldehyde occurred (Kader, 1986; Ke et al., 1991c; Smilanick and Fouse, 1989).

In this paper, we analyze important factors that influence fruit tolerance to low- $\mathrm{O}_{2}$ atmospheres and determine whether conditions required for specific insect disinfestation are tolerated by the fruit species in question.

Received for publication 12 Nov. 1991. Accented for publication 8 June 1992. Research supported, in part, by grant no. 88-0618 from the California Department of Food and Agriculture, American President Lines, and the California Tree Fruit Agreement. We thank Hone. Zhou for his assistance in doing statistical analysis: The cost of publishing this paper was defrayed in part-by the payment of page charges. Under postal regulations, this paper therefore must be hereby marked advertisement solely to indicate this fact.

${ }^{1}$ To whom reprint requests should be addressed.
Materials and Methods

Materials and treatments. Fruits of 'Bing' cherry, 'Red Jim' nectarine, 'Angeleno' plum, 'Yellow Newtown' and 'Granny Smith' apples, and '20th Century' pear were obtained on the day of harvest from commercial shippers in San Joaquin, Fresno, Montery, San Joaquin, and Solano counties of California, respectively. They were transported in an air-conditioned car to our laboratory at the Univ. of California, Davis, where they were kept overnight at $0 \mathrm{C}$. Experiments were initiated the next morning. Overripe fruits and those with defects were culled and five to 20 good fruits were put into a 4-liter glass jar as one replicate. Three replicates were used per treatment in a flowthrough system at a flow rate that maintained $\mathrm{CO}_{2}$ concentration within the container $<0.3 \%$. In one series of experiments, the fruit samples were kept in air and in the insecticidal $\mathrm{O}_{2}$ concentrations of $0.25 \% \pm 0.02 \%$ or $0.02 \%$ (by mixing $\mathrm{N}_{2}$ with air using needle valves to control flow rate of each gas) at 0 , 5 , or $10 \mathrm{C}$ for 3 days before they were used for the determinations of respiration rate, internal $\mathrm{CO}_{2}$ concentration, and resistance to gas diffusion. In another series of experiments, fruit samples were kept in the stated atmospheres at 0,5 , or $10 \mathrm{C}$ for 7 to 45 days followed by storage in air at $0 \mathrm{C}$ for 6 to 7 days to allow ethanol content to decrease. Then, the fruits were ripened in air at 20C for 1 to several days before final quality evaluation. An exception was cherries, which were not transferred to $20 \mathrm{C}$ since the fruits were ripe when harvested.

Gas analysis. The $\mathrm{O}_{2}$ and $\mathrm{CO}_{2}$ concentrations were measured by analysis of a 10-ml gas sample using an electrochemical $\mathrm{O}_{2}$ analyzer (model S-3AII, Applied Electrochemistry, Sunnyvale, Calif.) in series with an infrared $\mathrm{CO}_{2}$ analyzer (model PIR-2000, Horiba Instrument, Irvine, Calif.). Respiration rate was estimated from the $\mathrm{CO}_{2}$ concentration measured in the headspace of the jar holding the fruits, the flow rate used, and the fresh weight of the sample. Vacuum extraction was used to determine internal $\mathrm{CO}_{2}$ concentration and resistance to gas diffusion (Ke

Abbreviations: C, concentration; CA, controlled atmosphere; IS, intercellular spaces; R, respiration rate; r, resistance; RQ, respiratory quotient; SSC, soluble solids concentration; $\mathrm{T}$, temperature. 
and Kader, 1990). Resistance to $\mathrm{CO}_{2}$ diffusion was calculated by the ratio: $\left[(\mathrm{CO} 2)_{\text {Int. }}-\left(\mathrm{CO}_{2}\right)_{\text {Ext. }}\right] / \mathrm{CO}_{2}$ production rate. Intercellular space volume was estimated by determining the total amount of gases from the fruits after $30 \mathrm{~min}$ of vacuum extraction.

Determination of quality attributes. Three initial samples of five to 20 fruits each were evaluated for appearance, skin color, flesh firmness, SSC, $\mathrm{pH}$, titratable acidity as percent malic acid, ethanol content, and flavor score. Similar measurements were done as part of the final quality evaluations. Appearance was scored using a subjective scale of 1 to 5 where $5=$ excellent, 4 = good, 3 = fair, 2 = slight defects, $1=$ severe defects. Skin color was measured with a Gardner XL-23 Tristimulus Colorimeter (Gardner Laboratory, Bethesda, Md.). Flesh firmness was measured as penetration force with a Univ. of California firmness tester (Western Industrial Supply Co., San Francisco) fitted with an 8-mm plunger tip. Fruit juice was extracted with a hand-press juicer. SSC was measured with an Abbe refractometer, and $\mathrm{pH}$ and titratable acidity were measured with an automatic titrator (Radiometer, Copenhagen, Denmark) with a PHM85 Precision $\mathrm{pH}$ meter, an AUB80 autoburette, a PRS12 Alpha printer, and a SAC80 sample changer.

Determination of ethanol content. Ethanol in fruit juice was measured using a HP5890A gas chromatograph (Hewlett Packard, Palo Alto, Calif.) as described by Ke et al. (1991b).

Estimation of flavor score. Flavor of three fruits per treatment was evaluated by tasting as previously described (Ke et al., 1991b) using a scale of 1 to 7 where $7=$ excellent, $6=$ good, 5 = fair, $4=$ slight off-flavor, $3=$ moderate off-flavor, $2=$ severe off-flavor, and $1=$ extreme off-flavor.

Estimation of low $\mathrm{O}_{2}$ injury. Internal injury severity was visually estimated using a pretransformed scale of 1 to 5 according to the percentage of brown area of the fruit's longitudinal section: $1=$ no injury; 2 = slight injury, $1 \%$ to $15 \%$ of the area with browning; $3=$ moderate injury, $16 \%$ to $50 \%$ browning; $4=$ severe injury, $51 \%$ to $85 \%$ browning; $5=$ extreme injury, $86 \%$ to $100 \%$ browning.

Statistical analysis. Data were treated for multiple comparisons by analysis of variance with least significant difference (LSD) between means determined at $P=0.05$. The REG procedure (SAS Institute, 1985) was used for multiple regression analysis.

\section{Results and Discussion}

Fruit quality. 'Bing' cherries were ripe at harvest, as indicated by SSC $(17 \%)$ and titratable acidity $(0.84 \%)$. Exposure to $0.25 \%$ or $0.02 \% \mathrm{O}_{2}$ retarded darkening of the red pigment of the fruits, especially at $5 \mathrm{C}$. There were no significant differences among treatments in overall appearance quality, $\mathrm{SSC}, \mathrm{pH}$, and titratable acidity. Decay was negligible and no low $-\mathrm{O}_{2}$ injury was observed during the 35 days of storage at 0 or $5 \mathrm{C}$.

Exposure of cherries to $0.25 \%$ or $0.02 \% \mathrm{O}_{2}$ resulted in accumulation of ethanol (Fig. $1 \mathrm{~A}$ and $\mathrm{B}$ ), which was associated with a decrease in flavor score (Fig. $1 \mathrm{C}$ and D). These effects were much more pronounced with $0.02 \% \mathrm{O}_{2}$. A flavor score of 4 (slight alcoholic off-flavor) or lower value rendered the fruit unacceptable in taste. Therefore, the number of days to reach a flavor score of 4 was considered as the tolerance limit $(\mathrm{T}$,$) of$ the commodity to low $-\mathrm{O}_{2}$ treatments. By linear extrapolation from Fig. $1 \mathrm{C}$ and $\mathrm{D}$, the tolerance limits from the experiments $\left(\mathrm{T}\right.$, ,) were 25.3 and 21.3 days for $0.02 \% \mathrm{O}_{2}$ at 0 and $5 \mathrm{C}$, respectively.

'Red Jim' nectarines were red when harvested and no signif-

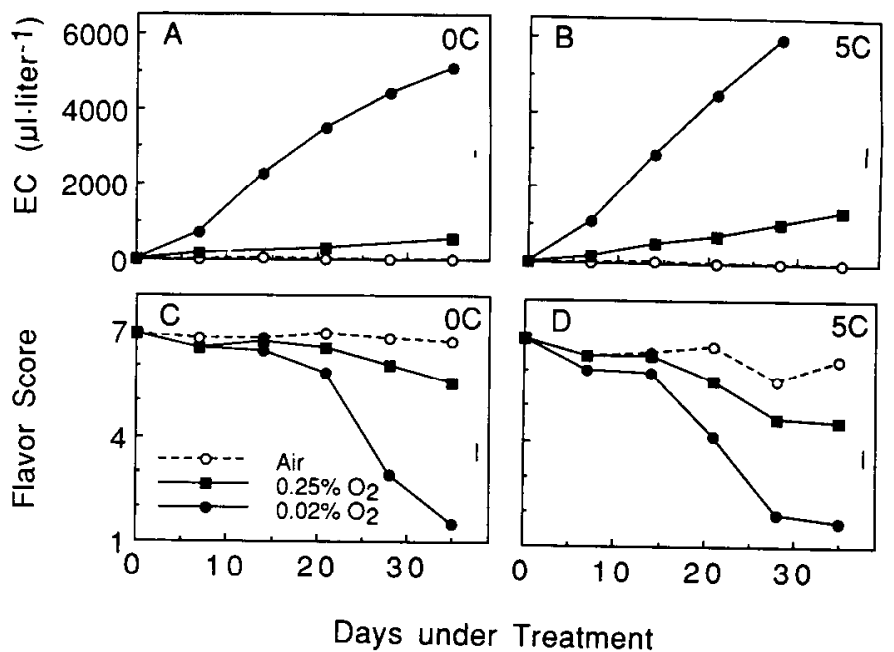

Fig. 1. Effects of temperature and $\mathrm{O}_{2}$ level on ethanol content (EC) and flavor score of 'Bing' cherries. The fruits were kept in air, $0.25 \% \mathrm{O}_{2}$, or $0.02 \% \mathrm{O}_{2}$ at 0 or $5 \mathrm{C}$ for $7,14,21,28$, or 35 days followed by transfer to air at $0 \mathrm{C}$ for 7 days. Flavor score was estimated using a scale of 1 to 7 where $7=$ excellent, $6=\operatorname{good}, 5=$ fair, 4 = slight off-flavor, $3=$ moderate off-flavor, $2=$ severe off-flavor, 1 = extreme off-flavor. Vertical bars represent LSD values at $P=0.05$.

icant change in red skin occurred during storage as a result of any of the treatments (data not shown). No injury was observed in the fruits kept in air at 0 or $10 \mathrm{C}$ or in $0.25 \% \mathrm{O}_{2}$ at $0 \mathrm{C}$, but internal injury was observed in nectarines exposed to $0.02 \% \mathrm{O}_{2}$ at 0 or $10 \mathrm{C}$ or to $0.25 \% \mathrm{O}_{2}$ at $10 \mathrm{C}$ for $>14$ days. Visual symptoms of low- $\mathrm{O}_{2}$ injury in nectarines included flesh browning that started near the stone and progressed toward the skin. In its advanced stage, the whole flesh turned dark brown, skin became brown and/or showed pitting, and the flesh became water-soaked and mushy. Injury symptoms usually became more pronounced after transfer of the fruit to air for a few days following low- $\mathrm{O}_{2}$ treatments. An internal injury score of 2 (slight injury) required 11 to 12 days in $0.02 \% \mathrm{O}_{2}$ at 0 or $10 \mathrm{C}$ or in $0.25 \% \mathrm{O}_{2}$ at $10 \mathrm{C}$.

Before visual symptoms of injury were observed, low $\mathrm{O}_{2}$ treated nectarines were firmer than air control fruits, especially at $10 \mathrm{C}$. In addition, fruits exposed to low $\mathrm{O}_{2}$ softened slower than the air control fruits upon transfer to air at $20 \mathrm{C}$ for ripening.

During storage SSC of nectarines remained $\approx 14 \%$, titratable acidity decreased from $\approx 0.8 \%$ to $\approx 0.5 \%$, and $\mathrm{pH}$ increased from $\approx 3.5$ to $\approx 3.9$. However, neither storage temperature nor $\mathrm{O}_{2}$ level significantly influenced the changes in titratable acidity and $\mathrm{pH}$ of the fruits.

The low $-\mathrm{O}_{2}$ treatments significantly increased ethanol content of nectarines (Fig. 2 A and B). This effect was much more obvious at 10C. Flavor of newly harvested 'Red Jim' nectarines was excellent and remained so in the fruits kept in air at 0 or 10C for up to 21 days (Fig. $2 \mathrm{C}$ and D). Flavor of the fruits exposed to $0.25 \% \mathrm{O}_{2}$ at $0 \mathrm{C}$ was similar to or slightly lower than that of air control fruits for up to 21 days. For fruits kept in $0.02 \% \mathrm{O}_{2}$ at 0 or $10 \mathrm{C}$ or in $0.25 \% \mathrm{O}_{2}$ at $10 \mathrm{C}$, the flavor score decreased sharply after 7 days, probably due to rapid ethanol accumulation. Linear extrapolation from Fig. $2 \mathrm{C}$ and D gave tolerance limits $\left(\mathrm{T}_{\mathrm{le}}\right)$ of 14.0, 12.8, and 10.5 days for 'Red Jim' nectarines kept in $0.02 \% \mathrm{O}_{2}$ at $0 \mathrm{C}, 0.25 \% \mathrm{O}_{2}$ at $10 \mathrm{C}$, and $0.02 \%$ 0 , at $10 \mathrm{C}$, respectively.

The effects of storage temperature and $\mathrm{O}_{2}$ level on $\mathrm{CO}_{2}$ pro- 


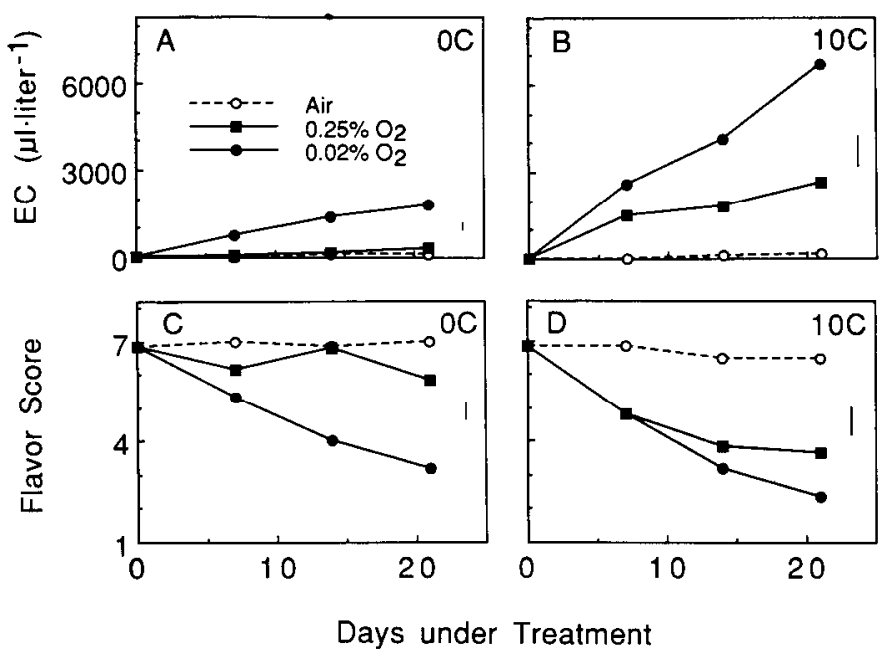

Fig. 2. Effects of storage temperature and $\mathrm{O}_{2}$ level on ethanol content (EC) and flavor score of 'Red Jim' nectarines. The fruits were kept in air, $0.25 \% \mathrm{O}_{2}$ or $0.02 \% \mathrm{O}_{2}$ at 0 or $10 \mathrm{C}$ for 7,14 , or 21 days followed by transfer to air at $0 \mathrm{C}$ for 6 days and then to air at $20 \mathrm{C}$ for 1 to 4 days. Flavor score was estimated using the same scale mentioned in the legend of Fig. 1. Vertical bars represent LSD values at $P=0.05$.

duction rate, resistance to $\mathrm{CO}_{2}$ diffusion, SSC and tolerance limits ( $\mathrm{T}_{\mathrm{le}}$, based on occurrence of off-flavor) of 'Bing' cherries, 'Red Jim' nectarines, 'Angeleno' plums, "Yellow Newtown' and 'Granny Smith' apples, and '20th Century' pears are summarized in Table 1.

Prediction of fruit tolerance to low $\mathrm{O}_{2}$. Among the fruits we tested, 'Red Jim' nectarine and '20th Century' pear were the only two commodities in which low- $\mathrm{O}_{2}$ injury was observed during short-term exposure to $0.02 \%$ or $0.25 \% \mathrm{O}_{2}$ at 0 to $10 \mathrm{C}$. However, alcoholic off-flavor was noted in all the commodities tested after various durations of low- $\mathrm{O}_{2}$ treatments.

Development of off-flavor in fruits is thought to be caused by accumulation of ethanol, acetaldehyde, ethyl acetate, and probably some other volatile compounds formed under anaerobic conditions. Ke et al. (1991b) indicated that flavor score and ethanol content have a logarithmic relationship and that fruit tolerance $\left(\mathrm{T}_{1}\right)$ to low $\mathrm{O}_{2}$ could be predicted by the following equation:

$$
\mathrm{T}_{1}=\mathrm{E}_{\mathrm{o}} / \mathrm{V}_{\mathrm{E}}=\left(10^{0.228 \mathrm{ssC}}\right) / \mathrm{V}_{\mathrm{E}}
$$

where $E_{o}$ is the threshold ethanol content for off-flavor detection and $\mathrm{V}_{\mathrm{E}}$ is the average ethanol accumulation rate per day under a low- $\mathrm{O}_{2}$ treatment. This model is simple to use since only two variables (SSC and $\mathrm{V}_{\mathrm{E}}$ ) are involved, but it requires a relatively longer period for measuring ethanol accumulation rate.

Ethanol is a product of anaerobic respiration under limited $\mathrm{O}_{2}$ supply. Internal $\mathrm{O}_{2}$ concentration $\left(\mathrm{C}_{\mathrm{i}}\right)$ for aerobic/anaerobic transition is a critical point. $\mathrm{C}_{\mathrm{i}}$ must be maintained higher than this transition point to prevent ethanol accumulation. If $\mathrm{C}_{\mathrm{i}}$ is lower than the transition point, anaerobic respiration rate and ethanol accumulation rate will be negatively correlated to $\mathrm{C}_{\mathrm{i}}$, and $\mathrm{T}$, will be positively correlated to $\mathrm{C}_{\mathrm{i}}$. This relationship can be expressed by:

$$
\mathrm{T}_{1} \propto \mathrm{C}_{\mathrm{i}}
$$

The relationship of resistance to $\mathrm{O}_{2}$ diffusion (r), external $\mathrm{O}_{2}$

Table 1. Tolerance limits from experiments $\left(\mathrm{T}_{\mathrm{le}}\right)$ and predicted tolerance limits $\left(\mathrm{T}_{1}\right)$ to low $\mathrm{O}_{2}$ by using temperature $(\mathrm{T}), \mathrm{O}_{2}$ concentration $(\mathrm{C})$, respiration rate $(\mathrm{R})$, resistance to $\mathrm{CO}_{2}$ diffusion $\left(\mathrm{rCO}_{2}\right.$ or $\left.\mathrm{r}\right)$, and soluble solids concentration (SSC) of six commodities as variables. Both $\mathrm{R}$ and $\mathrm{r}$ were measured after 3

\begin{tabular}{|c|c|c|c|c|c|c|c|c|}
\hline Commodity & $\begin{array}{l}\text { Temp } \\
\left({ }^{\circ} \mathrm{C}\right)\end{array}$ & $\begin{array}{l}\mathrm{O}_{2} \\
(\%)\end{array}$ & $\begin{array}{l}\mathrm{CO}_{2} \text { production rate } \\
\left(\mathrm{ml} \cdot \mathrm{kg}^{-1} \cdot \mathrm{h}^{-1}\right)\end{array}$ & {$\left[\% \cdot \frac{\mathrm{rO}_{2}}{\left[\% \cdot\left(\mathrm{ml} \cdot \mathrm{kg}^{-1} \cdot \mathrm{h}^{-1}\right)^{-1}\right]}\right.$} & $\begin{array}{l}\text { SSC } \\
(\%)\end{array}$ & $\begin{array}{c}\mathrm{T}_{\text {le }} \\
\text { (days) }\end{array}$ & $\begin{array}{c}\mathrm{T}_{1} \\
\text { (days) }^{\mathbf{z}}\end{array}$ & $\begin{array}{l}\mathrm{T}_{1 e}-\mathrm{T}_{\mathrm{l}} \\
\text { (days) }\end{array}$ \\
\hline \multirow[t]{4}{*}{ 'Bing' cherry } & 0 & 0.25 & 2.7 & 0.14 & 16.0 & 43.8 & 43.3 & 0.5 \\
\hline & 0 & 0.02 & 3.4 & 0.13 & 16.0 & 25.3 & 28.0 & -2.7 \\
\hline & 5 & 0.25 & 3.6 & 0.10 & 16.0 & 38.1 & 33.0 & 5.1 \\
\hline & 5 & 0.02 & 4.3 & 0.11 & 16.0 & 21.3 & 24.4 & -3.1 \\
\hline \multirow[t]{4}{*}{ 'Red Jim' nectarine } & 0 & 0.25 & 2.6 & 0.14 & 13.2 & 28.0 & 35.0 & -7.0 \\
\hline & 0 & 0.02 & 2.5 & 0.16 & 13.2 & 14.0 & 20.1 & -6.1 \\
\hline & 10 & 0.25 & 9.0 & 0.07 & 13.2 & 13.0 & 11.1 & 1.9 \\
\hline & 10 & 0.02 & 10.6 & 0.08 & 13.2 & 10.5 & 8.6 & 1.9 \\
\hline \multirow{4}{*}{ 'Angeleno' plum } & 5 & 0.25 & 2.2 & 0.63 & 15.3 & 40.6 & 29.7 & 10.9 \\
\hline & 5 & 0.02 & 3.2 & 0.46 & 15.3 & 31.6 & 21.6 & 10.0 \\
\hline & 10 & 0.25 & 3.7 & 0.40 & 15.3 & 14.0 & 19.8 & -5.8 \\
\hline & 10 & 0.02 & 4.5 & 0.41 & 15.3 & 9.4 & 17.9 & -8.5 \\
\hline \multirow[t]{4}{*}{ 'Yellow Newtown' apple } & 5 & 0.25 & 3.7 & 2.0 & 13.4 & 11.3 & 17.2 & -5.9 \\
\hline & 5 & 0.02 & 3.6 & 2.2 & 13.4 & 9.9 & 8.3 & 1.6 \\
\hline & 10 & 0.25 & 6.2 & 1.5 & 13.4 & 8.2 & 7.7 & 0.5 \\
\hline & 10 & 0.02 & 6.2 & 1.8 & 13.4 & 7.0 & 5.1 & 1.9 \\
\hline \multirow[t]{4}{*}{ 'Granny Smith' apple } & 0 & 0.25 & 1.2 & 1.6 & 11.9 & 23.4 & 26.0 & -2.6 \\
\hline & 0 & 0.02 & 1.4 & 1.7 & 11.9 & 11.9 & 10.5 & 1.4 \\
\hline & 10 & 0.25 & 4.4 & 1.1 & 11.9 & 7.0 & 6.2 & 0.8 \\
\hline & 10 & 0.02 & 4.2 & 1.1 & 11.9 & 5.0 & 5.0 & 0.0 \\
\hline \multirow{4}{*}{ '20th Century' pear } & 0 & 0.25 & 0.8 & 0.23 & 10.7 & 35.0 & 28.4 & 6.6 \\
\hline & 0 & 0.02 & 1.0 & 0.21 & 10.7 & 16.2 & 13.5 & 2.7 \\
\hline & 5 & 0.25 & 1.6 & 0.21 & 10.7 & 13.1 & 18.1 & -5.0 \\
\hline & 5 & 0.02 & 1.6 & 0.24 & 10.7 & 11.0 & 9.9 & 1.1 \\
\hline
\end{tabular}
days of treatment and SSC was measured in ripe fruits.

${ }^{\mathrm{z}}$ Predicted by Eq. [6]: $\mathrm{T}_{1}=-0.484 \mathrm{~T}+64.6 \mathrm{C}-0.722 \mathrm{R}-4.20 \mathrm{r}+3.00 \mathrm{SSC}-5.90 \mathrm{~T} \times \mathrm{C}-$ 18.2. 
concentration $\left(\mathrm{C}_{\mathrm{o}}\right)$, internal $\mathrm{O}_{2}$ concentration, and $\mathrm{O}_{2}$ consumption rate or respiration rate $(\mathrm{R})$ can be expressed as:

$$
r=\left(C_{o}-C_{i}\right) / R
$$

Rearrangement of Eq. [3] gives:

$$
\mathrm{C}_{\mathrm{i}}=\mathrm{C}_{\mathrm{o}}-\mathrm{Rr}
$$

Replacing Eq. [4] for $\mathrm{C}_{\mathrm{i}}$ in formula [2], then:

$$
\mathrm{T}_{1} \propto\left(\mathrm{C}_{\mathrm{o}}-\mathrm{Rr}\right)
$$

According to formula [5], $\mathrm{T}_{1}$ could be influenced by $\mathrm{C}_{0}, \mathrm{R}$, and $\mathrm{r}$. Since it is extremely difficult to determine $\mathrm{O}_{2}$ consumption rate and resistance to $\mathrm{O}_{2}$ diffusion $\left(\mathrm{rO}_{2}\right)$ at the extremely low $\mathrm{O}_{2}$ concentrations $(0.02 \%$ to $0.25 \%)$, we used $\mathrm{CO}_{2}$ production rate and resistance to $\mathrm{CO}_{2}$ diffusion $\left(\mathrm{rCO}_{2}\right)$ in the quantitative analysis when these replacements are permitted. Usually, $\mathrm{rO}_{2}$ and $\mathrm{rCO}_{2}$ are similar but not identical and the same is true for $\mathrm{O}_{2}$ consumption rate and $\mathrm{CO}_{2}$ production rate.

Oxygen concentration $\left(\mathrm{C}_{\mathrm{o}}\right)$ is directly proportional to $\mathrm{T}_{1}$. Since $\mathrm{Rr}$ is always a positive value, $\mathrm{C}_{\mathrm{o}}$ must be higher than the aerobic/anaerobic transition point to provide enough $\mathrm{C}_{o}$ to maintain aerobic respiration. If $\mathrm{Rr}$ is relatively high, then higher external $\mathrm{O}_{2}$ concentration is required to maintain $\mathrm{C}_{\mathrm{i}}$ level above the transition point to prevent ethanol accumulation. In the cases that $\mathrm{C}_{\mathrm{i}}$ is below the aerobic/anaerobic transition point, $\mathrm{V}_{\mathrm{E}}$ decreases and $\mathrm{T}_{1}$ increases as $\mathrm{C}_{\mathrm{o}}$ is raised. This relationship is clearly shown in Table 1 where $0.25 \% \mathrm{O}_{2}$ always gave higher $\mathrm{T}$, values than those of $0.02 \% \mathrm{O}_{2}$ for the same commodity at the same temperature.

Under aerobic conditions, the respiratory quotient $(\mathrm{RQ})$ is $\approx 1$ in most cases. Under anaerobic conditions, $\mathrm{CO}_{2}$ production rate exceeds $\mathrm{O}_{2}$ consumption rate resulting in an RQ value higher than 1 . A commodity with a relatively high respiration rate $(\mathrm{R})$ under low- $\mathrm{O}_{2}$ requires a relatively high $\mathrm{C}_{\mathrm{o}}$ to maintain aerobic respiration. In cases where $C_{i}$ is lower than the aerobic/anaerobic transition point, ethanol accumulates faster and $\mathrm{T}$, decreases as $\mathrm{R}$ increases. According to formula [5], a commodity with a low respiration rate usually tolerates low $\mathrm{O}_{2}$ better than one with a high rate if the other conditions are the same.

Resistance to gas diffusion (r) usually depends on the structure of the dermal system of the commodity; but postharvest treatments, such as waxing and film wrapping, can greatly increase $r$ values. A commodity with a high $r$ value would require a higher $\mathrm{C}_{\mathrm{o}}$ to maintain aerobic respiration than one with a low value. Under anaerobic conditions, a high $\mathrm{r}$ would also limit the diffusion of ethanol out of the commodity, increasing $\mathrm{V}$, Since $\mathrm{rO}_{2}$ is usually positively correlated to $\mathrm{rCO}_{2}$, the later could be used for approximate analysis. According to formula [5], a commodity with a relatively high resistance to gas diffusion would be less tolerant to low $\mathrm{O}_{2}$ than one with a lower resistance. The values of $\mathrm{r}$ for the same commodity may also change during maturation. Ripe fruits usually have higher $\mathrm{r}$ values and are more sensitive to low- $\mathrm{O}_{2}$ treatments than mature-green fruits.

Storage temperature $(\mathrm{T})$ can influence both $\mathrm{R}$ and $\mathrm{r}$. As $\mathrm{T}$ was raised, respiration rate increased but resistance to gas diffusion decreased (Table 1). However, the effect of temperature on $\mathrm{R}$ was greater than its effect on $\mathrm{r}$. For example, as $\mathrm{T}$ changed from $0 \mathrm{C}$ to $10 \mathrm{C}$, $\mathrm{R}$ changed by 3.0 - to 4.3 -fold, while $\mathrm{r}$ changed by 1.4- to 2.0-fold (Table 1). Therefore, as temperature increases, the tolerance to low $\mathrm{O}_{2}$ decreases. Raising $\mathrm{T}$ greatly increases $\mathrm{R}$ and reduces $\mathrm{O}_{2}$ solubility in solution and, therefore, a higher $C_{o}$ is required to maintain aerobic respiration. Meanwhile, there is a strong temperature $/ \mathrm{O}_{2}$ concentration interac- tion. $\mathrm{T}$, was 1.5 to 2.5 times higher at $0.25 \% \mathrm{O}_{2}$ than at $0.02 \%$ at $0 \mathrm{C}, 1.4$ to 2.0 times at $5 \mathrm{C}$, and 1.1 to 1.5 times higher at 10C (Table 1).

The SSC of the commodity when ripe was not substantially influenced by the $\mathrm{O}_{2}$ level or temperature during short-term storage treatments. Commodities with high SSC values, such as cherry and plum, generally were more tolerant to low $\mathrm{O}_{2}$ than those with lower SSC values (Table 1).

Ethanol is very soluble in water; its diffusion through intercellular spaces (IS) is much faster than through a liquid phase. The abundance of IS in a commodity may influence ethanol diffusion. The IS volumes for '20th Century' pear, 'Bing' cherry, 'Angeleno' plum, 'Red Jim' nectarine, 'Granny smith' apple, and 'Yellow Newtown' apple were 3.3\%, 3.6\%, 4.2\%, 6.7\%, $14 \%$, and $16 \%$, respectively. However, statistical analysis did not indicate a consistent and significant influence of IS on T, probably because IS is related to $r$ or because $r$ masks the effect of IS. In fruits, such as apples and oranges [Citrus sinensis (L.) Osb.], skin is the major barrier for gas diffusion. However, in fruits with very small IS volumes, such as Asian pear, flesh resistance may make a substantial contribution to $r$.

Based on multiple regression analysis (REG procedure, SAS, 1985) of data from Table 1, a model of important factors influencing fruit tolerance to low $\mathrm{O}_{2}$ is generated:

$$
\begin{aligned}
\mathrm{T}_{1}=-0.484 \mathrm{~T} & +64.6 \mathrm{C}-0.722 \mathrm{R}-4.20 \mathrm{r} \\
& +3.00 \mathrm{SSC}-5.90 \mathrm{~T} \times \mathrm{C}-18.2
\end{aligned}
$$

where $\mathrm{T}=$ temperature used, $\mathrm{C}=$ external $\mathrm{O}_{2}$ concentration used, $\mathrm{R}=\mathrm{CO}_{2}$ production rate, $\mathrm{r}=$ resistance to $\mathrm{CO}_{2}$ diffusion, and $\mathrm{SSC}=$ soluble solids content. Eq. [6] indicates that relatively high temperature, respiration rate, and resistance to gas diffusion reduce fruit tolerance to low- $\mathrm{O}_{2}$ atmospheres; relatively high $\mathrm{O}_{2}$ concentration and SSC increase fruit tolerance. Interaction between temperature and $\mathrm{O}_{2}$ concentration is also involved in this model.

A correlation coefficient of 0.902 was obtained for Eq. [6] at $P<0.0001$. This model could reasonably predict $\mathrm{T}$, in most cases and the average difference between observed tolerance and predicted tolerance is $\approx 4$ days (Table 1). In Eq. [6], T and $\mathrm{C}$ are predetermined or specified, $\mathrm{R}$ and $\mathrm{r}$ are measured after 3 days of low- $\mathrm{O}_{2}$ treatment, and $\mathrm{SSC}$ is commodity specific that is measured after the fruits are allowed to ripen.

It should be noted that this regression model is limited to $\mathrm{T}$ of 0,5 , and $10 \mathrm{C}$ and $\mathrm{C}$ of $0.25 \%$ and $0.02 \%$. For other temperatures and $\mathrm{O}_{2}$ concentrations, this model should be used with care or modified as needed.

Since $\mathrm{T}$ influences both $\mathrm{R}$ and $\mathrm{r}$ (Table 1), variables $\mathrm{R}$ and $\mathrm{r}$ are not completely independent in Eq. [6]. The interaction between $\mathrm{T}$ and $\mathrm{C}$ also reduces the accuracy of using this model for predicting $T_{1}$. To improve prediction accuracy, individual models for each temperature $(0,5$, and 10C) were developed as follows:

For 0C

$$
\mathrm{T}_{1}=54.2 \mathrm{C}-12.2 \mathrm{R}-7.23 \mathrm{r}+6.56 \mathrm{~S}-39.8
$$

For Eq. [7], correlation coefficient $=0.984, P=0.013$, average difference between $\mathrm{T}_{\mathrm{le}}$ and $\mathrm{T}_{1}=1.6$ days (Table 2).

For 5C

$$
\mathrm{T}_{1}=14.5 \mathrm{C}-9.90 \mathrm{R}-1.07 \mathrm{r}+7.68 \mathrm{~S}-56.0
$$

For Eq. [8], correlation coefficient $=0.986, P=0.011$, average difference between $\mathrm{T}_{\mathrm{le}}$ and $\mathrm{T}_{1}=1.6$ days $($ Table 2 ). 
Table 2. Comparison of tolerance limits from experiments $\left(\mathrm{T}_{\mathrm{e}}\right)$ and predicted tolerance limits $(\mathrm{T}$, ) to low $\mathrm{O}_{2}$ by using $\mathrm{O}_{2}$ concentration $(\mathrm{C})$, respiration rate $(\mathrm{R})$, resistance to $\mathrm{CO}_{2}$ diffusion $(\mathrm{r}$ ), and soluble solids concentration (SSC) of six commodities as variables at specified temperatures.

\begin{tabular}{|c|c|c|c|c|c|c|c|c|c|}
\hline \multirow[b]{2}{*}{ Commodity } & \multirow[b]{2}{*}{$\begin{array}{c}\text { Temp } \\
\left({ }^{\circ} \mathrm{C}\right)\end{array}$} & \multirow[b]{2}{*}{$\begin{array}{l}\mathrm{O}_{2} \\
(\%)\end{array}$} & \multirow[b]{2}{*}{$\begin{array}{c}\mathrm{T}_{1 \mathrm{e}} \\
\text { (days) }\end{array}$} & \multicolumn{2}{|c|}{ OC model $^{z}$} & \multicolumn{2}{|c|}{$5 \mathrm{C}$ model ${ }^{\mathrm{y}}$} & \multicolumn{2}{|c|}{$10 \mathrm{C}$ model $^{\mathrm{x}}$} \\
\hline & & & & $\begin{array}{c}\mathrm{T}_{1} \\
\text { (days) }\end{array}$ & $\begin{array}{c}\mathrm{T}_{\mathrm{le}}-\mathrm{T}_{1} \\
\text { (days) }\end{array}$ & $\begin{array}{c}\mathrm{T}_{1} \\
\text { (days) }\end{array}$ & $\begin{array}{c}\mathrm{T}_{\mathrm{le}}-\mathrm{T}_{1} \\
\text { (days) }\end{array}$ & $\begin{array}{c}\mathrm{T}_{1} \\
\text { (days) }\end{array}$ & $\begin{array}{c}\mathrm{T}_{1 \mathrm{e}}-\mathrm{T}_{1} \\
\text { (days) }\end{array}$ \\
\hline \multirow[t]{4}{*}{ 'Bing' cherry } & 0 & 0.25 & 43.8 & 44.6 & -0.8 & & & & \\
\hline & 0 & 0.02 & 25.3 & 23.7 & 1.6 & & & & \\
\hline & 5 & 0.25 & 38.1 & & & 34.8 & 3.3 & & \\
\hline & 5 & 0.02 & 21.3 & & & 24.5 & -3.2 & & \\
\hline \multirow{4}{*}{ 'Red Jim' nectarine } & 0 & 0.25 & 28.0 & 27.5 & 0.5 & & & & \\
\hline & 0 & 0.02 & 14.0 & 16.1 & -2.1 & & & & \\
\hline & 10 & 0.25 & 13.0 & & & & & 12.1 & 0.9 \\
\hline & 10 & 0.02 & 10.5 & & & & & 9.7 & 0.8 \\
\hline \multirow[t]{4}{*}{ 'Angeleno' plum } & 5 & 0.25 & 40.6 & & & 42.7 & -2.1 & & \\
\hline & 5 & 0.02 & 31.6 & & & 29.7 & 1.9 & & \\
\hline & 10 & 0.25 & 14.0 & & & & & 13.5 & 0.5 \\
\hline & 10 & 0.02 & 9.4 & & & & & 11.1 & -1.7 \\
\hline \multirow[t]{4}{*}{ 'Yellow Newtown' apple } & 5 & 0.25 & 11.3 & & & 11.8 & -0.5 & & \\
\hline & 5 & 0.02 & 9.9 & & & 9.2 & 0.7 & & \\
\hline & 10 & 0.25 & 8.2 & & & & & 8.6 & -0.4 \\
\hline & 10 & 0.02 & 7.0 & & & & & 5.4 & 1.6 \\
\hline \multirow[t]{4}{*}{ 'Granny Smith' apple } & 0 & 0.25 & 23.4 & 25.6 & -2.2 & & & & \\
\hline & 0 & 0.02 & 11.9 & 9.9 & 2.0 & & & & \\
\hline & 10 & 0.25 & 7.0 & & & & & 8.0 & -1.0 \\
\hline & 10 & 0.02 & 5.0 & & & & & 5.7 & -0.7 \\
\hline \multirow[t]{4}{*}{ '20th Century' pear } & 0 & 0.25 & 35.0 & 32.5 & 2.5 & & & & \\
\hline & 0 & 0.02 & 16.2 & 17.7 & -1.5 & & & & \\
\hline & 5 & 0.25 & 13.1 & & & 13.8 & -0.7 & & \\
\hline & 5 & 0.02 & 11.0 & & & 10.4 & 0.6 & & \\
\hline
\end{tabular}

${ }^{\mathrm{z}}$ Predicted by Eq. [7]: $\mathrm{T}_{1}=54.2 \mathrm{C}-12.2 \mathrm{R}-7.23 \mathrm{r}+6.56 \mathrm{SSC}-39.8$.

${ }^{\mathrm{y}}$ Predicted by Eq. [8]: $\mathrm{T}_{1}=14.5 \mathrm{C}-9.90 \mathrm{R}-1.07 \mathrm{r}+7.68 \mathrm{SSC}-56.0$.

${ }^{\mathrm{x}}$ Predicted by Eq. [10]: $\mathrm{T}_{1}=10.3 \mathrm{C}-2.60 \mathrm{r}+1.06 \mathrm{SSC}-4.35$.

For $10 \mathrm{C}$

$$
\mathrm{T}_{1}=11.4 \mathrm{C}+0.352 \mathrm{R}-1.88 \mathrm{r}+1.30 \mathrm{~S}-10.4[9]
$$

For Eq. [9], correlation coefficient $=0.963, P=0.046$, average difference between $\mathrm{T}_{1 \mathrm{e}}$ and $\mathrm{T}_{1}=0.7$ days. In Eq. [9], the regression coefficient of 0.352 is small compared to those of $\mathrm{C}, \mathrm{r}$, and SSC and statistically not significant $(P=0.224)$. Since the influence of $\mathrm{R}$ on $\mathrm{T}$, should be negative according to formula [5], the involvement of $\mathrm{R}$ data in the model did not appear to be appropriate and it was removed to obtain the following model:

$$
\mathrm{T}_{1}=10.3 \mathrm{C}-2.60 \mathrm{r}+1.06 \mathrm{~S}-4.35
$$

For Eq. [10], correlation coefficient $=0.934, P=0.029$, average difference between $\mathrm{T}_{1 \mathrm{e}}$ and $\mathrm{T}_{1}=0.9$ days (Table 2).

Comparing Eq. [6] to Eqs. [7], [8], and [10], it appears that the prediction accuracy is increased by developing models for each temperature.

Comparison of fruit tolerance and insect disinfestation by low $\mathrm{O}_{2}$. We recently summarized the limited published information about the time required to completely kill specific insects at specified $\mathrm{O}_{2}$ and $\mathrm{CO}_{2}$ concentrations and temperatures ( $\mathrm{Ke}$ and Kader, 1992). Comparing fruit tolerances to such conditions, there are many cases where insecticidal atmospheres are tolerated by fruits. For example, San Jose scale (Quadraspidiotus perniciasus), apple rust mite (Aculus schlechtendali), European red mite (Panonychus ulmi), and codling moth (Cydia pomonelb) could be killed by CA without detrimental effects on apples (Gaunce et al., 1982; Ke and Kader, 1989; Lidster et al., 1981, 1984; Morgan and Gaunce, 1975). Similarly, Caribbean fruit fly (Anastrepha suspensa) in citrus, thrips (Frankliniella occidentials) in strawberry, and leafroller (Planotortrix excessana) and mealy bug (Pseudococcus longispinus) in persimmon reach $100 \%$ mortality before detrimental effects are observed in the host commodities (Aharoni et al., 1979, 1981; Benshoter, 1987; Dentener et al., 1990; Ke and Kader, 1990; Ke et al., 1991a). However, apple maggot (Rhagoletis pomonella) is not completely killed before detrimental effects occur in apple under low- $\mathrm{O}_{2}$ treatment at 0 or 20C (Ali Niazee et al., 1989; Ke et al., 1991b; Kosittrakun, 1989). For nectarine, $0.5 \% \mathrm{O}_{2}$ at $25 \mathrm{C}$ was not feasible for control of codling moth because detrimental effects were observed in the host fruits after 3 days of low $-\mathrm{O}_{2}$ treatment (Soderstrom et al., 1987). Thus, CA appears to have a potential as a replacement to chemicals for postharvest insect disinfestation in some commodities and some insects.

\section{Literature Cited}

Aharoni, Y., P. Hartsell, J.K. Stewart, and D.K. Young. 1979. Control of western flower thrips on harvested strawberries with acetaldehyde in air, $50 \%$ carbon dioxide or $1 \%$ oxygen. J. Econ. Entomol. 72:819-822.

Aharoni, Y., J.K. Stewart, and D.G. Guadagni. 1981. Modified atmospheres to control western flower thrips on harvested strawberries. J. Econ. Entomol. 74:338-340.

Ali Niazee, M.T. Richardson, M. Kosittrakun, and A.B. Mohammed. 1989. Non-insecticidal quarantine treatment for apple maggot control in harvested fruit, p. 193-205. In: Proc. 5th Intl. Controlled Atmosphere Res. Conf., Wenatchee, Wash., 14-16 June 1989, vol. 1.

Benshoter, C.A. 1987. Effects of modified atmospheres and refrigeration temperatures on survival of eggs and larvae of the Caribbean 
fruit fly (Diptera:Tephritidae) in laboratory diet. J. Econ. Entomol. 80:1223-1225.

Chen, P.M., W.M. Mellenthin, S.B. Kelly, and T.J. Facteau. 1981. Effects of low oxygen and temperature on quality retention of 'Bing' cherries during prolonged storage. J. Amer. Soc. Hort. Sci. 106:533535 .

Dentener, P.R., E.A. MacRae, and P.J. Jackson. 1990. Insect disinfestation of New Zealand persimmons. Abstr. no. 2163, p. 518. In: Abstracts of contributed papers, 23rd Intl. Hort. Congr., Firenze, Italy, 27 Aug. to 1 Sept. 1990.

Gaunce, A.,P., C.V. Morgan, and M. Meheriuk. 1982. Control of tree fruit insects with modified atmospheres, p. 383-390. In: D.G. Richardson and M. Meheriuk (eds.). Controlled atmospheres for storage and transport of perishable agricultural commodities. Timber Press, Beaverton, Ore.

Kader, A.A. 1986. Biochemical and physiological basis for effects of controlled and modified atmospheres on fruits and vegetables. Food Technol. 40(5):99-100, 102-104.

Ke, D., L. Goldstein, M. O’Mahony, and A.A. Kader. 1991a. Effects of short-term exposure to low $\mathrm{O}_{2}$ and high $\mathrm{CO}_{2}$ atmospheres on quality attributes of strawberries. J. Food Sci. 56:50-54.

Ke, D. and A.A. Kader. 1989. Tolerance and responses of fresh fruits to oxygen levels at or below 1\%, p. 209-216. In: Proc. 5th Intl. Controlled Atmosphere Res. Conf., Wenatchee, Wash., 14-16 June 1989, vol. 2.

Ke, D. and A.A. Kader. 1990. Tolerance of 'Valencia' oranges to controlled atmospheres as determined by physiological responses and quality attributes. J. Amer. Soc. Hort. Sci. 115:779-783.

Ke, D. and A.A. Kader. 1992. Potential of controlled atmospheres for postharvest insect disinfestation of fruits and vegetables. Postharvest News and Info. 3(2):31N-37N.

Ke, D., L. Rodriguez-Sinobas, and A.A. Kader. 1991b. Physiology and prediction of fruit tolerance to low oxygen atmospheres. J. Amer. Soc. Hort. Sci. 116:253-260.

Ke, D., L. Rodriguez-Sinobas, and A.A. Kader. 1991c. Physiological responses and quality attributes of peaches kept in low oxygen atmospheres. Scientia Hort. 47:295-303.

Ke, D., H. van Gorsel, and A.A. Kader. 1990. Physiological and quality responses of 'Bartlett' pears to reduced- $\mathrm{O}_{2}$ and enhanced$\mathrm{CO}_{2}$ atmospheres and storage temperature. J. Amer. Soc. Hort. Sci. 115:435-439.

Kosittrakun, M. 1989. Effects of near anaerobic conditions on physiology and flavor of various fruit types and on mortality of apple maggot (Rhagoletiss pomonella). PhD Diss., Oregon State Univ., Corvallis.

Lidster, P.D., K.H. Sanford, and K.B. MacRae. 1981. Effects of modified atmosphere storage on overwintering populations of apple rust mite and European red mite eggs. HortScience 16:328-329.

Lidster, P.D., K.H. Sanford, and K.B. MacRae. 1984. Effects of temperature and controlled atmosphere on the survival of overwintering populations of European red mite eggs on stored 'McIntosh' apple. HortScience 19:257-258.

Morgan, C.V.G. and A.P. Gaunce. 1975. Carbon dioxide as a fumigant against the San Jose scale (Homoptera:Diaspididae) on harvested apples. Can. Entomol. 107:935-936.

Patterson, M.E. 1982. CA storage of cherries, p. 149-154. In: D.G. Richardson and M. Meheriuk (eds.). Controlled atmospheres for storage and transport of perishable agricultural commodities. Timber Press, Beaverton, Ore.

SAS Institute. 1985. The REG procedure, p. 655-709. In: SAS user's guide: Statistics. version 5 (ed.). Gary, N.C.

Smilanick, J.L. and D.C. Fouse. 1989. Quality of nectarines stored in insecticidal low- $\mathrm{O}_{2}$ atmospheres at 5 and 15C. J. Amer. Soc. Hort. Sci. 114:431436.

Soderstrom, E.L., D.G. Brandl, and B. MacKey. 1990. Responses of codling moth (Lepidoptera: Torticidae) life stages to high carbon dioxide or low oxygen atmospheres. J. Econ. Entomol. 83:472-475.

Soderstrom, E.L., D.G. Brandl, and J.C. Smilanick. 1987. Controlled atmospheres for postharvest control of codling moth on fresh tree fruits. 1986 Res. Rpt., California Tree Fruit Agreement, Sacramento.

Wang, C.Y. and R.E. Anderson. 1982. Progress of controlled atmosphere storage and intermittent warming of peaches and nectarines, p. 221-228. In: D.G. Richardson and M. Meheriuk (eds.). Controlled atmospheres for storage and transport of Perishable agricultural commodities. Timber Press, Beaverton, Ore. 